\title{
CONSEQUENCES ATTRIBUTED TO KIDNEY TRANSPLANTATION: CRITICAL INCIDENT TECHNIQUE ${ }^{1}$
}

\author{
Bianca Pozza dos Santos², Eda Schwartz³, Margrid Beuter', Rosani Manfrin Muniz', Maria Elena Echevarría- \\ Guanilo $^{6}$, Aline da Costa Viegas ${ }^{7}$
}

1 Taken from the dissertation - The experiences of people with kidney transplantation, presented to the Faculdade de Enfermagem of the Universidade Federal de Pelotas (UFPel) in 2013.

2 Doctoral student, Faculdade de Enfermagem and Graduate Nursing Program, UFPel. Pelotas, Rio Grande do Sul, Brazil. E-mail: bi.santos@bol.com.br

${ }^{3}$ Ph.D. in Nursing. Professor, Faculdade de Enfermagem and Graduate Nursing Program, UFPel. Pelotas, Rio Grande do Sul, Brazil. E-mail: eschwartz@terra.com.br

${ }^{4}$ Ph.D. in Nursing. Professor, Faculdade de Enfermagem, Universidade Federal de Santa Maria, Santa Maria, Rio Grande do Sul, Brazil. E-mail: margridbeuter@gmail.com

${ }^{5}$ Ph.D. in Nursing. Lecturer, Faculty of Nursing, UFPel. Pelotas, Rio Grande do Sul, Brazil. E-mail: romaniz@terra.com.br

${ }^{6}$ Ph.D. in Nursing. Professor, Department of Nursing, Universidade Federal de Santa Catarina. Florianópolis, Santa Catarina, Brazil. E-mail: elena_meeg@hotmail.com

${ }^{7}$ Doctoral student, Faculdade de Enfermagem and Graduate Nursing Program, UFPel. Pelotas, Rio Grande do Sul, Brazil. E-mail: alinecviegas@hotmail.com

ABSTRACT: This study aimed to describe the consequences experienced in the life of a person with kidney transplantation. This is a descriptive and qualitative approach, using the Critical Incident Technique, in which the interview content was analyzed, in an attempt to isolate the consequences of the kidney transplantation, showing positive and/or negative references. When confronted with what kidney transplantation provided to people's life, the independence from the hemodialysis machine, the existence of a quiet and normal life, the sensation of well-being, and the possibility of performing activities were demonstrated. In compensation, the transplantation provided changes that led them to another reality. Although some changes in the life of these people occurred, the process of transplantation did not represent significant change, which could install suffering.

DESCRIPTORS: Renal insufficiency, chronic. Kidney transplantation. Consequence analysis. Nursing.

\section{CONSEQUÊNCIAS ATRIBUÍDAS AO TRANSPLANTE RENAL: TÉCNICA DOS INCIDENTES CRÍTICOS}

RESUMO: Este estudo objetivou analisar as consequências acarretadas na vida da pessoa com o transplante renal. Possui abordagem qualitativa, do tipo descritivo, utilizando a Técnica dos Incidentes Críticos, em que analisou o conteúdo das entrevistas, almejando isolar as consequências positivas e negativas advindas após o transplante renal. Diante do que o processo de transplantação proporcionou na vida das pessoas, destacaram a independência do tratamento hemodialítico, a existência de uma vida tranquila e normal e a sensação de bem-estar. Em compensação, promoveu alterações que conduziram a uma nova realidade. Embora tenham acontecido mudanças na vida da pessoa, o transplante renal não representou alterações significativas que levassem ao sofrimento.

DESCRITORES: Insuficiência renal crônica. Transplante de rim. Análise de consequências. Enfermagem.

\section{CONSECUENCIAS ATRIBUIDAS AL TRASPLANTE DE RIÑÓN: TÉCNICA DE LOS INCIDENTES CRÍTICOS}

RESUMEN: Este estudio tuvo como objetivo analizar las consecuencias provocadas en la vida de las personas con trasplante de riñón. Tiene un enfoque cualitativo, descriptivo, utilizando la Técnica de Incidentes Críticos, que analizó el contenido de las entrevistas, con el objetivo de aislar las consecuencias positivas y negativas que surgen después de un trasplante de riñón. Así con todo lo que el proceso de trasplante proporcionó en las vidas de las personas, se destacaron la independencia de la hemodiálisis, la existencia de una vida tranquila y normal y la sensación de bien-estar. Aúnque, promovido cambios que llevaron a una nueva realidad. Aúnque se han producido cambios en la vida de uno, el trasplante renal no representó cambios significativos que llevarían al sufrimiento.

DESCRIPTORES: Insuficiencia renal crónica. Trasplante de riñón. Análisis de las consecuencias. Enfermería. 


\section{INTRODUCTION}

Chronic, non-communicable diseases (NCDs) were considered a health problem in developed countries, which had a significant elderly population. ${ }^{1}$ In the last years, more elderly people are living longer including in developing countries. ${ }^{2}$

Among the different types of diseases, NCDs are those likely to lead to significant changes in the lives of people. ${ }^{3}$ Living with NCD can generate feelings of powerlessness, confusion, anxiety and fear of death, as well as the loss of physical and mental well-being, social roles and routine, ${ }^{4}$ as in chronic renal failure $(\mathrm{CRF}){ }^{3}$

The manifestation of CRF ocurrs in a slow, progressive and irreversible way, in which, despite having treatment, there is no cure. ${ }^{5-6} \mathrm{In}$ addition, hydrogenated products (blood urea and creatinine) in the blood are the causes, making the kidneys unable to maintain the equilibrium of the human body. ${ }^{5}$ In this context, the person affected by this disease, is subjected to significant change in his daily routine, and a painful treatment is instituted to prevent early death, such as hemodialysis. ${ }^{6}$

The person receiving hemodialysis treatment suffers the imposition of new habits into their daily routine. More than 40 hours per month are spent in a hemodialysis unit, dependent on a machine to ensure the maintenance of life, with biopsychosocial losses that can generate psychological disorders such as fear of death, dependence on another person, a disturbed self-image, as well as damages to one's social context. ${ }^{3}$

With the obligation of hemodialysis, renal transplantation becomes much desired by the people with CRF, since it is considered a way to be free from the routine of hemodialysis treatment. It also enables returning to everyday life, ${ }^{7}$ resuming an affective, family and psychosocial routine that is closer to the usual. ${ }^{8}$

In this manner, transplantation is an alternative therapeutic intervention for dysfunction of a terminal organ, a fatal disease, or in some cases, to improve the quality of life and reduce the risk of chronic complications, ${ }^{9}$ such as CRF. Moreover, it has been considered the preferred choice as a procedure, allowing reintegration into social life, return to the work force, and improvement of one's physical and mental condition. ${ }^{10}$

While kidney transplantation is an important treatment modality, surgery is not a cure for the $\mathrm{CRF}$, but rather, it represents the possibility of a new life perspective and treatment, which will include ongoing medical care, use of immunosuppressive medication, and adherence to a plan of care whose objective is maintaining health. ${ }^{11}$

Moreover, the effectiveness of transplantation implies changes, as well as adaptations for performing daily and social activities. Still, if on one hand the person finds himself no longer requiring hemodialysis, on the other hand, she needs to stick to a routine of medications and may live with the fear of rejection of the transplanted organ. ${ }^{12}$

Among the numerous factors that permeate kidney transplantation, both positive and negative, in this study, the Critical Incident Technique (CIT) was used, which allows the visibility of consequences of a person with CRF, when subjected to kidney transplantation. Thus, the leading question was: What are the consequences in a person's life after kidney transplantation? The aim was to analyze the consequences brought to the daily life of a person with kidney transplantation, using the Critical Incident Technique.

\section{METHODS}

This study utilized a qualitative, descriptive approach in which the CIT, an analytical method, was used. The qualitative approach was chosen as it presents the possibility an in-depth study of collected data. The descriptive study helped in the description of what was observed. The CIT had the purpose of identifying factors experienced by a person at a given time. It consists of an incident collection process for later analysis and classification, in order to meet the objective of the study. From the reports provided, situations, behaviors and consequences can be characterized, with positive or negative references. ${ }^{13-15}$

The period of data collection occurred from May to July of 2013. Twenty people who met the inclusion criteria were interviewed: aged $\geq 18$ years; willingness to participate in the study, allowing the recording of interview and accepting the disclosure of the data within the scientific community; having sufficient mental faculties, and no reported difficulties in verbal communication; being linked to a nephrology service; being at least one year post-kidney transplantation, previously subjected to some dialysis treatment.

People subjected to kidney transplantation were contacted, from at least three nephrology services of a municipality located in the southern 
region of Rio Grande do Sul State. They were spoken to via telephone contact and invited to participate in this study, and were informed about the anonymity of information and that their participation was not obligatory. When they accepted, the date, time and place of the interviews were agreed upon.

Before initiating the interview, the Terms of Free and Informed Consent (IC) was presented, aiming to clarify any doubts and the procedures to be used in the study, ensuring voluntary participation, and the right to withdraw at any time. Later, two copies of the IC were signed; one was left with the interviewee and the other remained with the interviewer.

For data collection, two scripts of a semistructured interview were used. The first one had questions aimed at identifying the socioeconomic profile of respondents. The second, with semistructured questions for obtaining any critical incidents, encompassed questions about life after kidney transplantation, and what was considered easy or difficult. After data collection, the content analysis by CIT was performed, through a detailed reading, targeted to isolate the consequences attributed after kidney transplantation, with positive and/or negative references. ${ }^{16}$

Thereafter, categories were designed, involving consequences similar to each other, containing the name and operational definition of what it meant or represented for the person with kidney transplantation. For analysis by CIT, the categories were formulated in an exhaustive manner (including all cases obtained), mutually exclusive (each case should belong to a single category), and operationally defined, maintaining a high degree of consistency and coherence between them. ${ }^{16}$

The project was approved by the Research Ethics Committee of the Santa Casa Misericordia de Pelotas, protocol n. 192/2013, respecting the principles of Resolution 466/12 of the National Health Council ${ }^{17}$ and the principles of Resolution $311 / 2007$ of Federal Council of Nursing. ${ }^{18}$ The identification of respondents was presented by the letter E, followed by the Arabic numeral, as the sequence of interviews plus age (eg, E1, 43 years).

\section{RESULTS AND DISCUSSION}

The study had the participation of ten men and ten women, whose ages ranged between 30-66 years. According to statements made, 92 consequences arising from renal transplantation were identified; 19 were positive and 73 were negative. These consequences were distributed into two categories; the first related to the experience of the new reality brought about by the therapeutic modality, and the second, to the health care adopted.

\section{Experiencing the new reality after kidney transplant}

In relation to the experience of the new reality that kidney transplantation provided, 19 consequences were cited: 15 positive and four negative. The analysis of statements made by respondents shows that this therapeutic modality offered a life independent of hemodialysis treatment, a better way of scheduling their lives, defined as quiet and normal, with the feeling of well-being.

As the transplanted person no longer had an obligation to comply with the hemodialysis routine, the references were only positive about the independence from the hemodialysis machine [...] Yes, the liberation of the machine, ending that routine of three times a week, having to go to hospital to dialysis. Four hours per session. This is one of the major things [...] (E3, 40 years). [...] not having that commitment to the machine, it is well worth it [...] (E15, 39 years).

Kidney transplantation brings independence from the hemodialysis machine and the resumption of one's daily routine ${ }^{19}$ which was disrupted as a result of the CRF and its treatment by dialysis. As the hemodialysis treatment addressed the need for kidney filtration, it affects the person's autonomy, due to the inflexibility of dialysis, and the patient's obligation. Thus, kidney transplantation becomes a desired therapeutic since they provide returning to a normal life. ${ }^{20}$

Regarding the daily activities after kidney transplantation, positive consequences were found, in addition to the impact of freedom acquired through the disruption of hemodialysis treatment; the fact of making one's life better. These sentiments are shown in the following statements: [...] The effect of being able to do things that I could not, of power, of not having a schedule, of not having these things like, the routine of the machine, and I can do things better [...] (E3, 40 years). [...] I think you can better schedule your livelihood, as you need to take medicine, it is something that does not take even a minute to do. Now, you have to fit into your routine something that takes four hours, three times a week, it is complicated (E5, 30 years).

In contrast, the next statement refers to negative consequences, since, after kidney transplan- 
tation, some dreams were exchanged for others. Faced with high expectations, the person finds himself having to adapt his dreams to what is possible, since living with the transplant brings the experience of a new reality. [...] But, it is changed because you had some dreams which have had to be exchanged for others, then you end up living more within the reality [...]. Your goals, you cannot give up on your goals, but you have to moderate a little, be aware of reality; you know that you have your limits. [...] I had some dreams before that it would be possible; keeping up the work, that whole thing, then you have to rethink everything again [...] (E11, 54 years).

The statement of E5, 30 years, says that renal transplantation can be perceived by people with CRF as a way to be free from obligation of hemodialysis therapy, signaling the possibility of normal everyday living. ${ }^{7}$ Thus, there is a re-establishment of opportunities, allowing them to develop safe plans for their lives, including choices and thinking about the future; they recover, therefore, the autonomy lost to the disease. ${ }^{5}$

In addition, the transplantation process provides greater freedom compared to hemodialysis, which can enhance the person's perception about improving his life. ${ }^{21}$ It even makes the development of concrete plans feasible, ${ }^{22}$ without forgetting reality, as stated by E11, 54 years.

In regards to a quiet and normal life, one of the respondents expressed a positive consequence, this experience, despite concerns, is represented in the following statement: [...] despite all the concerns, I have my quiet life, so, I owe this to the transplant [...] (E11, 54 years).

On the other hand, an interviewee mentioned that, despite the normal life after transplantation, some negative changes ocurred; for example, she became a selfish person, resulting in her marital separation. [...] Normal, but with some changes, I became very selfish. I was married for seven years, I divorced. [...] I was carrying a child and I have carried my three children on my lap, and I think, I am a transplanted woman and I have to take care of myself [...]. I am no longer able to carry someone by hand. God forgive me, I've never been like that, but I am now [...] $(\mathrm{E} 13,53)$.

The consideration of a normal and quiet life is a complex and comprehensive concept, since it is characterized differently and associated with subjectivity; it can be felt through physical and psychological well-being and in the performance of daily activities. In general, transplanted people feel fulfilled with transplantation. They have an increased degree of satisfaction after living through hard times, and consider the experience of this moment as a new life, ${ }^{23}$ what is considered normal.

A study involving 16 participants showed that transplantation, as a treatment of choice, is considered a potential therapy that improves health and promotes the return to normality in addition to the freedom from dialysis. Generally, it has a positive effect on the life of a person with CRF, creating a greater sense of freedom, allowing returning to work, enjoyment of life again, ${ }^{24}$ often having a transformation, which significantly improves the quality of life. ${ }^{25}$

The transplantation is, in fact, the only chance for survival for patients waiting for organs such as a heart and liver; people who have CRF can rely on dialysis. Thus, these feeling of healing and rebirth often favor practices based on the notion that to receive a new kidney is to get better. It represents a return to one's previous condition, in which the natural kidney was working, therefore having a normal life. ${ }^{26}$

One thing to be noted in the lives of people who undergo this circumstance is that the process of chronic disease may imply changes in interpersonal relationships, and in the family environment, the most frequent place for adjustments. ${ }^{5}$ This occurrence reported by the interviewee E13, 53 years, is highlighted as a priority.

With regard to the sense of well-being, two respondents expressed only positive consequences. The first emphasized feeling fulfilled, and the second stated there was no reason to complain. [...] I feel fine, I feel fulfilled now [...] (E10, 46 years). [...] I'm fine, feeling well. I have no reason to complain about my transplantation, I'm feeling well (E12, 45 years).

The feeling of well-being is individual and may involve cultural and social factors. Thus, feeling good, expressed by respondents, could mean that the kidney transplantation constitutes the best therapy for CRF. In this context, it should be noted that well-being is subjective and influenced by individual perception of events experienced beyond the interpretations that each person will have. ${ }^{27}$ As well-being is linked to human subjectivity in relationship to health, it encompasses different aspects, including physical, cognitive and emotional health. ${ }^{28}$

\section{Health care adopted after kidney transplan- tation}

Regarding health care adopted after kidney transplantation, 73 consequences were found; four 
positives and 69 negatives. The higher number of negative references than positive shows a marked difference at each occurrence, as the transplantation process caused an obligation of using immunosuppressive medication, not performing labor activity, the finding that the durability of the transplanted organ is not eternal, and the constant search for knowledge of rights and how people should act.

Thus, when referring to health care, one of the interviewees expressed the importance of fluid intake; it contributes to the functioning of the transplanted organ. [...] It is to keep [the fluid intake], because the kidney, it does the cleaning, the blood passes and does the cleaning. Because what is not good for the organism pours into the urine. And without taking water, what do you urinate? Nothing. So I have to take enough water to always be cleaning the kidney [...] (E8, 50 years).

Regarding the negative consequences, the use of immunosuppressive drugs is mentioned; if the transplanted person does not use these, the kidney function will be lost. [...] Without taking [the immunosuppressive medication], the kidney stops, it depends on that to keep working, it depends on this medication [...] (E3, 40 years).

The daily routine of a transplanted person differs from a non-transplanted person, due to the necessary care to prevent infection; healthy and proper nutrition, weight maintenance and medication administration being rigorously schedulled. ${ }^{23}$ Although the respondents of this study demonstrate awareness about the precautions to be taken after kidney transplantation, lack of care can occur due to a false idea of curing the CRF. At this juncture, it is the responsibility of health professionals, especially those involved with the process of transplantation, to promote strategies related to education and provide guidance to people about their new lifestyle. Attempting, for example, to ensure adherence to the immunosuppressive therapy. ${ }^{21}$

With the risks of rejection after kidney transplantation, outpatient treatment is essential to prevent complications that could jeopardize the survival of the person or transplanted organ. Promoting guidelines on diet, medications, exercise, infection prevention, and identification of signs and symptoms that can lead to rejection are important strategies for successful treatment. ${ }^{29}$ Therefore, nurses must be involved in the health care of people with kidney transplantation, including the entire biopsychosocial aspect of the individual.
The nurse has an important role in the health team. This professional has the task of providing quality care to people through the use of technological, logistical and human resources, including the development of coordination, assistance, education and research in the field of transplantation. In this context, knowledge of the principles of good ethical practices and the resources available to assess the merits, risks and social issues related to transplants are important. ${ }^{30}$

With regard to the restriction on some activities after kidney transplantation, the only interviewee who pointed to a positive result mentioned the fact that the action of care is beneficial in order to avoid returning to hemodialysis. [...] There is none [restriction]. But it is good to have more attention [...], in order to avoiding having hemodialysis again (E17, 40 years).

On the other hand, one of the negative consequences is that the person cannot work again as he was used to doing before the kidney disease, since the type of activity performed before will not be allowed, even after transplantation. [...] My only problem, the only difference from my normal life is that I do not work anymore. I used to work in a school, I am unemployed now [...] and the service that I used to do at school, I will not be allowed to do anymore, which was to carry some weight [...]. Even going to the supermarket, to do my shopping and bring it with me, no, I cannot carry weight [...] (E13, 53 years).

One of the concepts arising from renal transplantation is the idea that the person with CRF could return to daily activities, ${ }^{5}$ which would include the realization of those activities previously performed, with the same intensity. Based on this belief, there is the statement from E13, 53 years old, that even considering his present life as normal, there is a disruption of certain activities due to physical limitations that need to be respected, aiming to maintain good health. Regardless of the adopted kidney treatment, CRF causes physical consequences that can generate psychological disorders in daily life, such as those activities that used to be common which must be left behind. ${ }^{31}$

As the transplant does not promote the healing of the CRF, nor is it eternal, one interviewee argued as a positive consequence the fact that trying to live one's life as best as he can in order to not affect one's mental health. [...] To live as best you can, if you will live in fear, you fail to do many things that you otherwise would do in a regular way [...]. But something like that, if that happens, what do you do? [...] (E14, 41 years). 
In contrast, the following statement illustrates a negative consequence, the discovery that this is not eternal, the possibility of losing the kidney, having to return to the hemodialysis machine. [...] The transplant improves life, but it cannot last forever. You might have it for a while and then, have to go back to the machine. There is no point to put that aside, if I know that there is a possibility of losing, of losing the transplanted kidney [...] (E3, 40).

The statement of E3, 40 years, shows that despite the successful kidney transplant, after hospital discharge the person continues to have a chronic disease, such as CRF. The risk of rejection remains, which can occur in acute and chronic form, as the graft acts as a foreign body in the body. $^{5}$

Many scientific disciplines address the transplantation as a procedure that allows the continuation of life and represents a rebirth. Transplantation saves lives that can be accounted for and explained in numbers and statistics. Therefore, it is considered a very desirable and valuable treatment; however, it is not a cure and does not mitigate all of the symptoms of CRF. ${ }^{26}$

As a palliative treatment, renal transplantation does not fully recover the health of the person with $\mathrm{CRF},{ }^{32}$ but it introduces possible disorders to the person. Consecutively, the person can present everyday limitations, experience numerous losses and psychological changes, with the possibility of direct interference on their mode of living. ${ }^{4}$

Among other negative consequences observed, a constant search for knowledge of rights and how they should act are mentioned. People who have been transplanted adopt strategies in order to remedy such weaknesses. There are consequences that could be avoided. [...] These rights, if the doctor did not tell me, there in [name of the health service], I did not know. He told me and [...] sent me to the Department of Health [...]. We have rights, anything, [...] if you do not work hard on them, they disregard you (E4, 55 years).

[...] And that is not very easy to know, it's such a world, where you have to interact with people [health professionals] from inside. If you demonstrate that you really feel good, that you want to have some help, that you are happy, that you are interested in your life and that you do everything for the transplant, you will have this reciprocity of your medical team. If you are an outdated person who is not committed to the cause, you will not have it. You have to seek the things, like everything in life, but especially in your health, you have to always seek. Always seek and demonstrate interest, demonstrate that you truly want to be transplanted, that you want to live well, that you want things to go right, then you would in a way have all the reciprocity from the medical staff [...] (E16, 40 years).

Such consequences arising in persons living with kidney transplantation could be avoided, because the Unified Health System (UHS) is the most responsible, not only for its performance, but for its maintenance. Thus, there is the guarantee of a free supply of immunosuppressive drugs, dialysis, clinical monitoring, diagnostic examinations and necessary hospitalizations, ${ }^{33}$ not requiring the adoption of strategies that lead to guarantee their rights. Given this context, we must stress that Brazil has one of the largest public health systems in the world, in which the process of transplantation and their maintenance are guaranteed by law to everyone in society.

Finally, the data found in this study allow us to infer that, despite the numerous limitations in the person's life with CRF, which can also occur with kidney transplantation, it continutes to be considered the best treatment option for kidney disease, as it provides a better quality of life. Thus, it is important to remember that, even by reducing the stressors generated in the daily routine by hemodialysis, people with CRF still live with a chronic disease, therefore requiring the use of continuous medication and regular clinical follow-up. ${ }^{34}$

\section{CONCLUSION}

Considering that renal transplantation has the aim of promoting a better quality of life for people with $C R F$, this study sought to analyze the positive and negative consequences attributed to this treatment modality. Thus, the independence of hemodialysis, the fact of getting better, planning for their lives, which is considered peaceful and normal, a feeling of well-being, the adoption of health care and the lack of some restrictions on activities to be performed was found. There were balanced factors related to changes in dreams, changes in interpersonal relationships, the obligation of immunosuppressive medication, missing one's labor activity, the finding that the durability of the transplanted organ does not last forever, and the constant search for knowledge of rights and how people should act.

Given these analyzed data, it was noted in the statements that, although changes happened in the person's life, the process of transplantation 
did not represent significant changes that would lead to suffering or despair. On the contrary, some attributed consequences of longing for a new life, and this was permeated by the better quality of life than what was experienced ruing hemodialysis.

Reflecting on this, the knowledge of experiences in post-renal transplant is necessary, in order to contribute both to the scientific community, as well as to the transplanted people themseleves. This is true especially within the nursing area, as this is a profession that remains close to the person with CRF for the largest amount of time. Still, when compared to other professional health categories, nurses becomes responsible for planning resources that generate good care for those who are receiving that care, so that they achieve autonomy with the new treatment adopted.

Therefore, it is expected that this study will contribute to the construction of knowledge related to the person's life after kidney transplantation. And thus, health professionals, particularly nurses, will acquire a theoretical basis to assist people in this life experience, which is permeated by positive and negative consequences.

\section{REFERENCES}

1. Veras RP. Estratégias para o enfrentamento das doenças crônicas: um modelo em que todos ganham. Rev Bras Geriatr Gerontol. 2011; 14(4):779-86.

2. Moura EC, Silva AS, Malta DC, Morais Neto OL. Fatores de risco e proteção para doenças crônicas: vigilância por meio de inquérito telefônico, VIGITEL, Brasil, 2007. Cad Saude Publica. 2011; 27(3):486-96.

3. Cardoso LB, Sade PMC. O enfermeiro frente ao processo de resiliência do paciente em tratamento hemodialítico. Rev Eletr Faculdade Evangélica do Paraná [online]. 2012 [acesso 2013 Set 23]; 02(1). Disponível em: http://www.fepar.edu.br/ revistaeletronica/index.php/revfepar/article/ download/35/45

4. Daugirdas JT, Blake PG, Ing TS. Manual de diálise. $4^{\mathrm{a}}$ ed. Rio de Janeiro (RJ): Guanabara; 2010.

5. Fontoura FAP. A compreensão de vida de pacientes submetidos ao transplante renal: significados, vivências e qualidade de vida [dissertação]. Campo Grande (MS): Universidade Católica Dom Bosco, Programa de Mestrado em Psicologia; 2012.

6. Santana SS, Fontenelle T, Magalhães LM. Assistência de enfermagem prestada aos pacientes em tratamento hemodialítico nas unidades de nefrologia. Rev Científica ITPAC. 2013; 6(3):1-11.

7. Pereira LP, Guedes MVC. Hemodiálise: a percepção do portador renal crônico. Cogitare Enferm. 2009; 14(4):689-95.
8. Persch O, Dani DM. Transplante renal intervivos: um olhar psicológico. Cad Ciênc Biol Saúde. 2013; (1):1-15.

9. Abdala E, Azevedo LSF, Campos SV, Caramori ML, Costa SF, Strabelli TMV, et al. Use of hepatitis C-positive donors in transplantation. Clinics. 2012; 67(5):517-9.

10. Silva FS. História oral de vida de pacientes transplantados renais: novos caminhos a trilhar [dissertação]. Natal (RN): Universidade Federal do Rio Grande do Norte. Centro de Ciências da Saúde; 2011.

11. Silva JM, Fialho AVM, Borges MCLA, Silva LMS. Perfil epidemiológico dos pacientes transplantados renais em hospital universitário e o conhecimento sobre uso de drogas imunossupressoras. JBT: J Bras Transpl. 2011; 14(1):1449-94.

12. Quintana AM, Weissheimer TKS, Hermann C. Atribuições de significados ao transplante renal. Rev Psico. 2011; 42(1):23-30.

13. Martins MFM. Estudo do uso do Portal da CAPES no processo de geração de conhecimento por pesquisadores da área Biomédica: aplicando a técnica do incidente crítico [dissertação]. Rio de Janeiro (RJ): Universidade Federal Fluminense; 2006.

14. Pereira MG. Conceitos básicos de epidemiologia. Rio de Janeiro (RJ): Guanabara Koogan; 2008.

15. Richardson RJ, Peres JAS, Wanderley JCV, Correia LM, Peres MHM. Pesquisa social: Métodos e técnicas. $3^{\mathrm{a}}$ ed. São Paulo (SP): Editora Atlas; 2011.

16. Dela Coleta JA, Dela Coleta MF. A técnica dos incidentes críticos: 30 anos de utilização no Brasil na Psicologia, Administração, Saúde e Educação. Taubaté (SP): Cabral editora e Livraria Universitária; 2004.

17. Ministério da Saúde (BR). Conselho Nacional de Saúde, Comissão Nacional de Ética em Pesquisa. Resolução n. 422 de 12 de dezembro de 2012: diretrizes e normas regulamentadoras de pesquisa envolvendo seres humanos. Brasília (DF): MS; 2012.

18. Conselho Federal de Enfermagem [página da Internet]. Código de Ética dos Profissionais de Enfermagem. Resolução COFEN 311/2007 [acesso 2012 Ago 13]. Disponível em: http:// www.portalcofen. gov.br/2007/materias. asp? ArticleID $=7323 \&$ sectionID $=37$

19. Gonçalves CS. As representações sociais sobre a doença renal crônica [dissertação]. Curitiba (PR): Universidade Federal do Paraná. Programa de PósGraduação em Enfermagem; 2012.

20. Medeiros AJS, Medeiros EMD. Desafios do tratamento hemodialítico para o portador de insuficiência renal crônica e a contribuição da enfermagem. REBES. 2013; 3(1):1-10.

21. Santos LVA, Santos AB, Costa CMA. Qualidade de vida relacionada ao domínio relação social em transplantados renais: estudo preliminar. Rev Hosp Univ Pedro Ernesto. 2011; 10(Supl.1):64-72. 
22. Barbosa KFS. A experiência em família frente à doença renal terminal e o transplante bem sucedido [dissertação]. Londrina (PR): Universidade Estadual de Londrina. Programa de Pós-Graduação em Enfermagem; 2013.

23. Aguiar MIF, Farias DR, Pinheiro ML, Chaves ES, Rolim ILTP, Almeida PC. Qualidade de vida de pacientes submetidos ao transplante cardíaco: aplicação da escala Whoqol-Bref. Arq Bras Cardiol. 2011; 96(1):60-7.

24. Gill P, Lowes L. Renal transplant failure and disenfranchised grief: participants' experiences in the first year post-graft failure - a qualitative longitudinal study. Int J Nurs Stud. 2014; 51(9):127180.

25. Gill P. Stressors and coping mechanisms in live related renal transplantation. J Clin Nurs. 2012; 21(11-12):1622-31.

26. Fernandes LF. Histórias de doação de rim: explorando narrativas e repertórios interpretativos de doadores [dissertação]. Fortaleza (CE): Universidade Federal do Ceará. Programa de Pós-Graduação em Psicologia; 2011.

27. Rodrigues DM, Pereira CAA. A percepção de controle como fonte de bem-estar. Estud Pesq Psicol. 2007; 7(3):541-56.

28. Kinoshita LN, Melo RC, Yassuda MS, Batistoni SS, Domingues MAR, Lopes A, et al. Doenças autorrelatadas e satisfação com a vida de participantes da Universidade Aberta à Terceira Idade da Escola de Artes Ciências e Humanidades da Universidade de São Paulo. Rev Temática Kairós Gerontol. 2012; 15(7):107-28.

29. Albuquerque JG, Lira ALBC, Lopes MVO. Fatores preditivos de diagnósticos de enfermagem em pacientes submetidos ao transplante renal. Rev Bras Enferm. 2010; 63(1):98-103.

30. Mendes KDS, Roza BA, Barbosa SFF, Schirmer J, Galvão CM. Transplante de órgãos e tecidos: responsabilidades do enfermeiro. Texto Contexto Enferm. 2012; 21(4):945-53.

31. Gazzinelli MF, Gazzinelli A, Reis DC, Penna CMM. Educação em saúde: conhecimentos, representações sociais e experiências da doença. Cad Saude Publica. 2005; 21(1):200-6.

32. Lira ALBC, Lopes MVO. Pacientes transplantados renais: análise de associação dos diagnósticos de enfermagem. Rev Gaucha Enferm. 2010; 31(1):10814.

33. Guerra Júnior AA, Acúrcio FA, Andrade EIG, Cherchiglia ML, Cesar CC, Queiroz OV, et al. Ciclosporina versus tacrolimus no transplante renal no Brasil: uma comparação de custos. Cad Saude Publica. 2010; 26(1):163-74.

34. Carvalho MTV, Batista APL, Almeida PP, Machado DM, Amaral EO. Qualidade de vida dos pacientes transplantados renais do Hospital do Rim. Motricidade. 2012; 8(Supl.2):49-57. 